\section{Clonally Propagated and Seed-derived Papaya Orchards: I. Plant Production and Field Growth}

\author{
Maureen M.M. Fitch ${ }^{1}$ and Paul H. Moore \\ Pacific Basin Agricultural Research Center, Aiea, HI 96701 \\ Terryl C.W. Leong, Leslie Ann Y. Akashi, Aileen K.F. Yeh, \\ Susan A. White, Amy S. Dela Cruz, and Lance T. Santo \\ Hawaii Agriculture Research Center, Aiea, HI 96701
}

\author{
Stephen A. Ferreira \\ College of Tropical Agriculture and Human Resources, University of Hawaii, \\ Honolulu, HI 96822
}

\section{Leslie J. Poland \\ DuPont Agriculture and Nutrition, Waialua, HI 96791}

\author{
Additional index words. Carica papaya L., hermaphrodites, micropropagation, rooted \\ cuttings, virus resistant papaya
}

\begin{abstract}
Papaya seedlings segregate for sex expression as females or hermaphrodites. Typically only hermaphrodite fruit are marketed in Hawaii. The agronomic practice of growing multiple seedlings that are later thinned to a single hermaphrodite tree is wasteful of seed, labor, and resources, especially when seed is costly. We compared growth of plants propagated by the clonal methods of micropropagation or rooting vegetative cuttings versus plants initiated as seedlings and transplanted. The seedlings were either single-planted hermaphrodites as identified by the polymerase chain reaction (PCR) or multiple-planted, thinned seedlings. The experiments were carried out in three different locations on two islands in Hawaii. Clonally propagated plants were significantly shorter than seedlings and bore flowers earlier and lower on the trunk at all locations. Stem diameter differences were not significant even though plant size was different at planting time. Percentage of trees in bud varied significantly in the third month after transplanting when about $90 \%$ of the rooted cuttings and large micropropagated plants had formed flower buds while only one multiple-planted seedling developed a bud. Overall, the clonally propagated plants were more vigorous and earlier bearing than were the seedling plants. There is good potential for adoption of clonal propagation when production becomes efficient enough to compete in price with the current practice of over planting and thinning.
\end{abstract}

Papaya (Carica papaya L.) is a polygamous species with all three sex forms: staminate (male), hermaphrodite, and pistillate (female). Sex is determined by a single gene with three alleles: $\mathrm{M}_{1}$, male; $\mathrm{M}_{2}$, hermaphrodite; and $\mathrm{m}$, female (Hofmeyr, 1938; Storey, 1938, 1941, 1953). Storey $(1939,1953)$ reported crossing experiments that showed every combination of dominant alleles, $M_{1} M_{1}, M_{1} M_{2}$, and $M_{2} M_{2}$, is lethal to the zygotes. Thus, males $\left(\mathrm{M}_{1} \mathrm{~m}\right)$ and hermaphrodites $\left(\mathrm{M}_{2} \mathrm{~m}\right)$ are enforced sex heterozygotes while females $(\mathrm{mm})$ are recessive homozygotes. A consequence of papaya's lethal sex allele is a skewed segregation of sex among seed obtained from different types of crosses. Seed obtained from female plants cross-pollinated by a hermaphrodite or a male will segregate one female to one hermaphrodite or male; seed obtained from self-pollinated

Received for publication 11 Nov. 2004. Accepted for publication 8 Jan. 2005. This research was funded in part by a University of Hawaii College of Tropical Agriculture and Human Resources Minor Crops Special Funds Grant. We thank C. and D. Gonsalves for help in planting.

${ }^{1}$ Corresponding author; e-mail mfitch@pbarc.ars. usda.gov. hermaphrodites will segregate one female to two hermaphrodites (Storey, 1953).

Hermaphrodite papaya trees are preferred for commercial production in Hawaii. Female papaya trees are not grown commercially as a result of their variably sized fruit and reduced seed content that leaves a large air space in the seed cavity as a result of unreliable crosspollination. In addition, the round shape of the female fruit requires greater container volume for shipping than does the more slender pyriform-shaped fruit of the hermaphrodite trees. Hermaphrodite papaya orchards are generally established by planting five to ten selfed hermaphrodite seeds in a single hole. In this system, seedlings are grown for 3 to 4 months before they are thinned to remove the female plants, leaving a single hermaphrodite tree. This system of over-planting followed a few months later by thinning to a single tree is not only wasteful of seed, water, and fertilizer, but also intra-plant competition for sunlight results in more spindly plant growth and later bearing than when plants are grown with wider spacing. The cost for establishing orchards might be reduced and earlier fruit harvests might be achieved if there were a way to solve the sex segregation problem and establish orchards with hermaphrodite plants from the start. Clonal propagation from hermaphrodite plants is one way to acquire plant propagules of known sex.

Clonal propagation of papaya would not only solve the problem of providing plants of known sex, the plants would also be true to genotype. Traditionally, Hawaii's papaya farmers have started orchards with farmer saved seed from selfed hermaphrodite inbred lines. Over the past few years, however, the predominant cultivar has been a transgenic $\mathrm{F}_{1}$ hybrid, 'Rainbow'. Selfed seed from 'Rainbow' segregates for numerous characters, including fruit color and quality and resistance to several diseases including papaya ringspot virus (PRSV), thus farmers must plant hybrid seed and there is no commercial supply. To avoid this problem, clonal propagation might be used to start a new crop. Clonal propagation could be through rooted cuttings taken from field- or greenhouse-grown trees or from shoots clonally multiplied in a laboratory tissue culture system, i.e., micropropagation.

Allan $(1964,1993)$ may have been the first to report a protocol for papaya cloning by rooting lateral branches of mature trees. Reuveni and Shlesinger (1990) increased the production of clonal propagules by using gibberellic acid $\left(\mathrm{GA}_{3}\right)$ and benzylaminopurine (BA) spray treatments to increase the emergence of lateral branches from decapitated, greenhouse-grown stock plants. A combined treatment of $2.2 \mathrm{~mm}$ BA and $2.6 \mathrm{mM} \mathrm{GA}_{3}$, applied in lanolin paste to each nodal bud, or three spray treatments of $2.2 \mathrm{~mm}$ BA and $0.3 \mathrm{mM} \mathrm{GA}_{3}$ were used to stimulate multiple shoot growth. The emerged thin branches, 8 to $12 \mathrm{~mm}$ in diameter, were dipped in talcum powder containing $10 \mathrm{~g} \cdot \mathrm{L}^{-1}$ benomyl and $49 \mathrm{~mm}$ indolebutyric acid (IBA) (potassium salt), placed in an aerated potting medium, and rooted with bottom heat $\left(30^{\circ} \mathrm{C}\right)$ and intermittent mist. A total of $85 \%$ to $100 \%$ of the cuttings rooted after $21 \mathrm{~d}$.

Papaya micropropagation was first reported by Litz and Conover (1977) and subsequently expanded (Chan and Teo, 2002; Drew, 1988; Drew et al., 1993; Drew and Vogler, 1993; Reuveni et al., 1990; and Yu et al., 2000). Field trials with clonally propagated papaya trees showed that they bore fruit earlier and lower on the trunk than did over-planted and thinned seedlings. In a trial in Queensland, Australia, flowering height was reduced from 1.5 to $2.0 \mathrm{~m}$ for typical thinned seedlings in a particular field to $0.3 \mathrm{~m}$ to $0.4 \mathrm{~m}$ for micropropagated plants (Drew, 1988). In another experiment, height of first flowers of micropropagated females derived from adult tissues were compared to single seedling females planted in different seasons (Drew and Volger, 1993). Micropropagated plants and seedlings planted in summer (February) bore flowers at significantly different heights, 43 and $56 \mathrm{~cm}$, respectively $(P=0.01)$. Micropropagated plants and seedlings planted in late spring (November) bore flowers at even more disparate and significantly different heights, 32 and $79 \mathrm{~cm}$, respectively $(P=0.01)$. In a trial conducted in Malaysia, three hermaphrodite 
seedling selections developed their first flowers at 98 to $128 \mathrm{~cm}$ while micropropagated plants from these lines developed their first flowers at 80 to $82 \mathrm{~cm}$ (Chan and Teo, 2002).

Harvesting is one of the more costly operations in papaya production, especially for tall trees. Harvesting of fruit higher than a person's reach, about $183 \mathrm{~cm}$, adds significant additional costs. Lower bearing trees help on harvest costs for a few months.

Because farmers need orchards with plants of known sex and genotype, there was a need for a study comparing tree growth and development and subsequent fruit yield in fields established from multiple-planted seedling transplants that are later thinned versus those established from clonally propagated rooted cuttings or micropropagated plants. In this, the first of two reports, we present results of establishing clonal propagules and field trials evaluating the growth and development of seedlings, rooted cuttings, and micropropagated plants in three locations over two years.

\section{Materials and Methods}

\section{Plant material}

All experiments were conducted with PRSV-resistant commercial papaya hybrid cultivar 'Rainbow'. 'Rainbow' papaya seeds were gifts of Richard Manshardt, University of Hawaii.

\section{Field sites}

Keaau. The first established and most extensively sampled test was at Keaau on the island of Hawaii. The test was installed on 30 Apr. 1998 in Papai, an extremely stony soil (USDA, 1972, 1973) within a 750-year-old to 1500 -year-old lava flow (USGS, 1996) at an elevation of $60 \mathrm{~m}$. The average daily temperature was $28^{\circ} \mathrm{C}$ in summer and $23^{\circ} \mathrm{C}$ in winter with a soil temperature range of 22 to $23{ }^{\circ} \mathrm{C}$. Rainfall at this site averages $381 \mathrm{~cm}$ annually (USDA, 1973). No additional irrigation is provided. The 30-year (1932 to 1975) solar radiation average from weather stations in Keaau ranged from $401 \mathrm{cal} \cdot \mathrm{cm}^{-2} \cdot \mathrm{d}^{-1}$ at 27 $\mathrm{m}$ elevation down to $377 \mathrm{cal} \cdot \mathrm{cm}^{-2} \cdot \mathrm{d}^{-1}$ at $87 \mathrm{~m}$ elevation(How, 1978). The test site, intermediate in elevation to the two stations, would be expected to receive solar radiation of about $389 \mathrm{cal} \cdot \mathrm{cm}^{-2} \cdot \mathrm{d}^{-1}$. Planting holes excavated in the lava were supplemented with about 15 L of Papai soil that had not been previously planted in papaya.

Helemano. The Helemano block was installed on 23 Oct. 1998 on the north shore of the island of Oahu. The Helemano site had a more weathered and less fertile Oxisol, the Lahaina silty clay. Elevation was $180 \mathrm{~m}$. The average daily temperature was $27^{\circ} \mathrm{C}$ in summer and $22^{\circ} \mathrm{C}$ in winter. The 30 -year average (1932 to 1975) solar radiation at the nearest weather station $(3.2 \mathrm{~km})$ was $468 \mathrm{cal} \cdot \mathrm{cm}^{-2} \cdot \mathrm{d}^{-1}$ at 210 $\mathrm{m}$ elevation (How, 1978). Helemano, similar to the Mokuleia site, received approximately $131 \mathrm{~cm}$ of rain per year and was drip-irrigated at 91.6 to $137.4 \mathrm{~m}^{-3} \cdot \mathrm{ha}^{-1} \cdot \mathrm{wk}^{-1}$ during the year except for periods of heavy rainfall.

Mokuleia. The Mokuleia block was in- stalled on 10 Mar. 1999 on the north shore of the island of Oahu. The Mokuleia site (elevation $=9$ $\mathrm{m})$ had a fertile Mollisol, the Waialua silty clay. The average daily temperature was $29^{\circ} \mathrm{C}$ in summer and $26^{\circ} \mathrm{C}$ in winter. The 30 -year average solar radiation at the nearest weather station $(6.4 \mathrm{~km})$ was $435 \mathrm{cal} \cdot \mathrm{cm}^{-2} \cdot \mathrm{d}^{-1}$ at $6 \mathrm{~m}$ elevation (How, 1978). The site received approximately $131 \mathrm{~cm}$ of rain per year and was drip-irrigated at 91.6 to $137.4 \mathrm{~m}^{-3} \cdot \mathrm{ha}^{-1} \cdot \mathrm{wk}^{-1}$ during the year except for periods of heavy rainfall.

\section{Field test design}

The experimental design was a randomized complete block with four or six replication plots containing three to five treatments as subplots consisting of a single row for each treatment. The treatments were designated as: CT, rooted cuttings; $\mathrm{MP}_{\mathrm{lg}}$, micropropagated plants 21 to $30 \mathrm{~cm}$ tall; $\mathrm{MP}_{\mathrm{sm}}$, micropropagated plants 12 to $20 \mathrm{~cm}$ tall; SD1, single seedlings; and SD5, five seedlings per hole. Subplots of treatments were randomized within each replication plot. The Keaau block was divided into four replication subplots containing five treatments $(\mathrm{CT}$, $\left.\mathrm{MP}_{\mathrm{lg}}, \mathrm{MP}_{\mathrm{sm}}, \mathrm{SD} 1, \mathrm{SD} 5\right)$ planted as single rows of 20 plants each randomized among subplots for a total test size of 400 plants. The Helemano block was divided into six replication subplots containing three treatments (CT, MP, SD5) planted as single rows of 10 plants each randomized among subplots for a total test size of 180 plants. The Mokuleia block was divided into four replication subplots containing four treatments (CT, MP, SD1, SD5) planted as single rows of 28 plants each randomized among subplots for a total test size of 448 plants. Tree spacing was $1.50 \mathrm{~m}$ between trees within a row and $3 \mathrm{~m}$ between rows. For the single-seedling treatment (SD1), a single SD was planted per hole. For the multiple-plant treatment, the SDs were planted five per hole (SD5), about $8 \mathrm{~cm}$ apart and thinned to a single hermaphrodite when flower buds appeared. To eliminate edge effects, each field block was surrounded by at least two border rows of SD5 plants of the same age as the test plants.

At all three sites, growers applied fertilizer and pest control chemicals according to their standard practice that consisted of broadcasting a formulation of $11 \mathrm{~N}-32 \mathrm{~K}_{2} \mathrm{O}$ fertilizer around each tree or they applied the formulation through the irrigation system at $20 \mathrm{~kg} \cdot \mathrm{ha}^{-1}$ per4 weeks during the first 3 months of growth and then increased rates to $80 \mathrm{~kg} \cdot \mathrm{ha}^{-1}$ per 4 weeks. Supplemental $\mathrm{K}_{2} \mathrm{O}$ fertilization was added if deficiency symptoms appeared.

\section{Micropropagation}

Twenty 'Rainbow' seeds were surface sterilized by agitation in $100 \mathrm{~mL}$ of $12.5 \mathrm{~g} \cdot \mathrm{L}^{-1}$ $\mathrm{NaOCl}$ (diluted commercial bleach) to which was added $100 \mu \mathrm{L}$ Tween 20 . After $1 \mathrm{~h}$, seeds were transferred to sterile $1.0 \mathrm{M} \mathrm{KNO}_{3}$ and agitated overnight, then transferred to 100 $\mathrm{mL}$ sterile water. After $5 \mathrm{~d}$ of imbibition with agitation at $32{ }^{\circ} \mathrm{C}$, the testae cracked and the seeds were transferred onto $10 \mathrm{~g} \cdot \mathrm{L}^{-1}$ agar for germination. Shoot tips were excised from 10d-old seedlings and transferred to Petri plates containing an MS salts medium (Murashige and Skoog, 1962) supplemented with 100 $\mathrm{mg} \cdot \mathrm{L}^{-1}$ myoinositol, $4 \mathrm{mg} \cdot \mathrm{L}^{-1}$ thiamine- $\mathrm{HCl}$, $30 \mathrm{~g} \cdot \mathrm{L}^{-1}$ sucrose, and $3 \mathrm{~g} \cdot \mathrm{L}^{-1}$ Phytagel (MSO medium) for $30 \mathrm{~d}$. The micropropagated plants (MP) were produced on de Fossard medium (de Fossard et al., 1974) by subculturing divided clumps of plants every 3 to 8 weeks. Later, the de Fossard proliferation medium was replaced with $\mathrm{MSO}+0.89 \mu \mathrm{M}$ benzylaminopurine (BA) and $1.1 \mu \mathrm{M}$ naphthalene acetic acid (NAA) (MBN medium, Yu et al., 2000) and subculturing was carried out every 3 to 8 weeks.

Shoots 1-cm long were placed in the dark for $5 \mathrm{~d}$ on $\mathrm{MSO}+9.84 \mu \mathrm{M}$ indolebutyric acid (IBA) to induce rooting (Drew et al., 1993). Induced shoots were transferred to $125-\mathrm{mL}$ baby food jars containing $25 \mathrm{~mL}$ vermiculite moistened with $30 \mathrm{~mL}$ of solution consisting of half-strength MSO containing $30 \mathrm{~g} \cdot \mathrm{L}^{-1}$ sucrose. Jars were maintained under cool white fluorescent lights $\left(35 \mu \mathrm{mol} \cdot \mathrm{m}^{-2} \cdot \mathrm{s}^{-1}\right)$ for 4 to 12 weeks to allow for root development. Rooted MPs were transplanted in perforated plastic bags half-filled with $30 \mathrm{~mL}$ vermiculite (Yu et al., 2000) or in $6 \times 6 \mathrm{~cm}$ plastic pots, 10 $\mathrm{cm}$ tall, filled with commercial peat-based potting mixture.

Potted MPs were acclimatized to laboratory conditions at $27{ }^{\circ} \mathrm{C}$ under clear plastic wrap and cool white fluorescent lights (35 $\left.\mu \mathrm{mol} \cdot \mathrm{m}^{-2} \cdot \mathrm{s}^{-1}\right)$. They were gradually vented over a 2-week interval (Yu et al., 2000). The MPs were grown in a greenhouse for at least 4 weeks, irrigated twice a day, fertilized with timed release granules $\left(14 \mathrm{~N}-14 \mathrm{P}_{2} \mathrm{O}_{5}-14 \mathrm{~K}_{2} \mathrm{O}\right.$ formulation), and acclimatized in sunlight for at least 2 weeks before planting in the field trials. About 350 MPs were acclimatized for the three field trials (Keaau, Helemano, and Mokuleia). Two sizes of MPs were included in the Keaau field test, large MPs (MP $)$ that were 21 to $30 \mathrm{~cm}$ tall and small MPs ( $\left.\mathrm{MP}_{\mathrm{sm}}\right)$ that were 12 to $20 \mathrm{~cm}$ tall.

\section{Rooted cuttings}

The MP lines served as stock plants for producing rooted cutting $(\mathrm{CT})$ plants used in the Keaau field test. Shoot cuttings, 10 to 25 $\mathrm{cm}$ long and 0.6 to $1.0 \mathrm{~cm}$ in diameter, were trimmed to two or three apical leaves, dipped in commercial rooting powder containing $0.1 \mathrm{~g}$ IBA per $100 \mathrm{~g}$ talc, and potted in 6-cm square plastic pots filled with $50 \%$ perlite and $50 \%$ vermiculite or $50 \%$ perlite and $50 \%$ peatbased potting mixture. The potted CTs were drenched with mancozeb fungicide diluted as recommended by the manufacturer (Dithane F-45; Dow Agrosciences, Indianapolis, Ind.), placed on heating mats $\left(29^{\circ} \mathrm{C}\right)$, and irrigated with mist in a continuous cycle of $5 \mathrm{~s}$ on, $10 \mathrm{~min}$ off. Rooted CTs were removed from the mist chamber, fertilized with $\left(14 \mathrm{~N}-14 \mathrm{P}_{2} \mathrm{O}_{5}-14 \mathrm{~K}_{2} \mathrm{O}\right)$ timed release granules, grown without heat, and irrigated twice a day by overhead sprinklers for about 4 weeks. CTs were acclimatized in sunlight for at least 2 weeks before field planting.

CTs for the Helemano and Mokuleia tests were grown from the greenhouse stocks and from lateral branches of mature trees in commercial orchards on Oahu. About 300 
rooted CTs were acclimatized for the three field tests.

\section{Seedlings}

About 5500 seedlings (SDs) were germinated for the three field tests including border rows. In total, 1800 SDs were required for the multiple-planted, thinned treatment (SD5); 600 SDs were tested for sex expression for the single-seedling (SD1) treatment; and 3000 SD5s were used to establish double-border rows surrounding each test.

Seeds were germinated in $2.5 \times 2.5 \times 3$ $\mathrm{cm}$ peat pots filled with a peat based potting mixture. Pots were irrigated twice a day with overhead sprinklers. After germination, SDs were fertilized with $\left(14 \mathrm{~N}-14 \mathrm{P}_{2} \mathrm{O}_{5}-14 \mathrm{~K}_{2} \mathrm{O}\right)$ timed release granules. SDs for the Keaau test were germinated and grown in the greenhouse to 3 months of age when they reached 15 to 20 $\mathrm{cm}$ tall and 3 to $4 \mathrm{~mm}$ in diameter. The Helemano and Mokuleia SDs were germinated in an outdoor nursery at Dole Co., Haleiwa, Hawaii, to 7 to 8 weeks of age when they reached 15 to $30 \mathrm{~cm}$ tall and 3 to $4 \mathrm{~mm}$ in diameter. Seedlings used for PCR testing were randomly selected from among the two batches.

\section{PCR for sex determination}

DNA was extracted from two leaves of seedlings macerated in CTAB extraction buffer (Dellaporta et al., 1983; Saghai-Maroof et al., 1984) as previously described (Fitch et al., 1992). PCR was performed using primers T1 (20-mer) and T12 (21-mer) (Deputy et al., 2002). The primers, developed from RAPD primers reported by Sondur et al. (1996), amplify a DNA fragment that is linked to the sex expression locus of papaya. All of the amplification reagents were obtained from Applied Biosystems, Foster City, Calif. Concentrations used were 1.5 units per $50 \mu \mathrm{L}$ Amplitaq gold polymerase, $2 \mathrm{mM} \mathrm{MgCl}_{2}, 200 \mu \mathrm{M}$ each dNTPs, $5 \mu \mathrm{L}$ per $50 \mu \mathrm{L} 10 \times$ buffer reaction, $0.02 \mathrm{mM}$ primers, and 2 ng per $50 \mu \mathrm{L}$ genomic DNA. The PCR conditions for 35 cycles were $8 \mathrm{~min}$ prewarm up, $1 \mathrm{~min}$ at $95^{\circ} \mathrm{C}$ denaturation, $1 \mathrm{~min}$ at $58^{\circ} \mathrm{C}$ annealing, and $2 \mathrm{~min}$ at $72^{\circ} \mathrm{C}$ extension. Gel electrophoresis was accomplished using a $1 \%$ agarose gel and $1 \times$ TBE buffer as reported earlier (Fitch et al., 1992). Hermaphrodites produced amplified bands at 1300 and $800 \mathrm{bp}$ and were identified by the 800 -bp band that was lacking in the females.

\section{Data collection and analysis}

Height and diameter to the nearest $0.5 \mathrm{~cm}$ and date of appearance and height on the tree of the first flower bud were taken at 4-week intervals on the all trees for 9 months in Keaau, only four times in 7 months in Helemano, and at 4-week intervals for 14 months in Mokuleia,. The differences in number of observations were a result of time constraints since the experiments were being carried out simultaneously. The early data in Keaau suggested that data collection in each 4-week interval was not necessary in Helemano, but monthly growth data collection was resumed in Mokuleia because tree growth in soil with irrigation differed from that in rainfed lava. For the SD5 treatment, values reported were the average for two of the healthiest-looking multiple-planted seedlings per planting hole until single hermaphrodites were selected. Trunk diameter measurements were taken at a height of 1 to $8 \mathrm{~cm}$ above the soil level. Data are presented as the mean of subplots (plant type or treatment) within the site block per month. Significance for the data was calculated from analysis of variance in treatment subplots and expressed as the least significant difference (LSD) per treatment per month at $P<0.05$ (Statistix 7 for Windows). Data were also analyzed for the effect of location and time by combining datasets for Keaau and Mokuleia.

\section{Results}

Plant propagation. The MPplants produced new shoots 1 to $4 \mathrm{~mm}$ long about two to three times per month. Multiple shoots excised from the mother clump of MPs rooted in 1 to 6 weeks when transferred to the vermiculite medium. Survival ex vitro was approximately $60 \%$. There were no phenotype variants among the 332 MPs in the three field tests.

PCR screening of 600 SD plants for sex expression identified 279 hermaphrodites for field planting. Growth of the 279 lines revealed a single female plant at Keaau and three female plants at Mokuleia. These female plants were chopped out of the sites, rescreened by PCR, and showed typical female banding patterns. This result indicated an error in our initial PCR screen.

About $90 \%$ of the CTs from greenhousegrown MP lines rooted in 2 to 6 weeks. Cuttings from field-grown trees had much lower rates of $10 \%$ to $30 \%$ for survival and rooting. Many of the field-grown branches rotted before roots developed in 4 to 12 weeks. A single female plant was discovered among the CTs at the Keaau site. This plant was identified by isozyme data as 'Kamiya' rather than 'Rainbow' (M. Aradhya, personal communication). This error was a result of to a mix up of plants in the greenhouse since 'Kamiya' females were routinely rooted in the greenhouse for a different project.

Field tests. Tree development data (height, diameter, flowering, and fruit set) taken monthly on the four types of plants used for starting orchards at two locations, Keaau and Mokuleia, showed highly significant $(P<$ $0.001)$ effects of plant type age and location on all sources of variation (Table 1). Height of the first bud was analyzed over 5 rather than 9 months because there were no data points in the first few measurements at either site and measurements were discontinued at Keaau after the seventh month of growth. Tree diameter was strongly influenced by date and location $(P<0.001)$ but not by plant type (NS). The low or lack of significance for replication of blocks within each test indicated fairly uniform plants within each type and a fairly uniform field for each replication. The Helemano site was not included in this analysis because data taken at this site consisted of four dates only. Because of the significant effect of location, tree development data could not be summarized across locations so results are presented separately for each location.

Trees derived from MPs, CTs, and SDs differed, sometimes significantly, in size as transplants and maintained these differences through 5 to 7 months after orchard establishment in Keaau (Fig. 1). However, cumulative growth measurements of trees from the first through ninth month after field establishment showed that the SD5 plants were smaller in diameter and taller (Table 2) giving them a spindly appearance early in the crop cycle (Fig. 1). The $\mathrm{MP}_{\text {lg }}$ group $(30.4 \mathrm{~cm})$ began significantly taller and thicker $(P<0.05)$ than the other treatments. By the second month, the $\mathrm{MP}_{\mathrm{lg}}$ were still taller than all other treatments, but by the third month, CT was the only group significantly shorter than $\mathrm{MP}_{1 \mathrm{~g}}$ Height differences in the subsequent months of growth were either not significantly different or significantly different only between the taller SD5s compared to CTs at the eighth and ninth months after planting. The CT plants were the shortest trees at the end of the test period. The MP $\mathrm{M}_{\mathrm{lg}}$ plants began and remained as the thickest in diameter while the SD plants were significantly thinner than the other treatments for 3 months. By the sixth month, diameters among treatments were not significantly different.

Clonally propagated plants, CTs and MPs, developed flowers earlier (Table 3 ) and lower on the tree (Table 4) compared to SDs. No flower buds were observed the first and second month after transplanting; however, in the third month, $>50 \%$ of the clonally propagated plants had developed buds (Table 3 ) at heights ranging from an average of 49 to $67 \mathrm{~cm}$ (Table 4). At this time, the SD1s had significantly fewer flower buds $(27 \%)$ than the clonally propagated plants but more than the SD5s $(<1 \%)$. In the fourth month, the percentage of SD1s in bud was not significantly different from the clonally planted trees but budding of all plant

Table 1. Analysis of variance (ANOVA) for growth in height and diameter as influenced by plant type (TYPE), month after transplanting (MON), and location (LOC).

\begin{tabular}{lccccc}
\hline $\begin{array}{l}\text { Source of } \\
\text { variation }\end{array}$ & df & $\begin{array}{c}\text { Tree ht } \\
(\mathrm{cm})\end{array}$ & $\begin{array}{c}\text { Tree diam } \\
(\mathrm{cm})\end{array}$ & $\begin{array}{c}\text { Ht of 1st } \\
\text { bud }(\mathrm{cm})\end{array}$ & $\begin{array}{l}\text { Trees in } \\
\text { bud }(\%)\end{array}$ \\
\hline Plant type (T) & 3 & $* * *$ & NS & $* * *$ & $* * *$ * \\
Month (M) & 8 & $* * *$ & $* * *$ & $* * *$ \\
Location (L) & 1 & $* * *$ & $* * *$ & NS & $* * *$ \\
Replication (R) & 3 & $*$ & $*$ & & NS \\
$\mathrm{T} \times \mathrm{M} \times \mathrm{L} \times \mathrm{R}$ & 272 & & &
\end{tabular}

${ }^{\mathrm{z} U s e d}$ only 5 months.

Two locations and 9 months of growth measurements analyzed, except for first bud height data which used data for only 5 months because there were too many missing data points during the months when no buds had formed.

${ }_{\mathrm{NS},{ }^{*}, * *, * * *}$ Nonsignificant or significant at $P<0.05,0.01$, or 0.001 , respectively. 


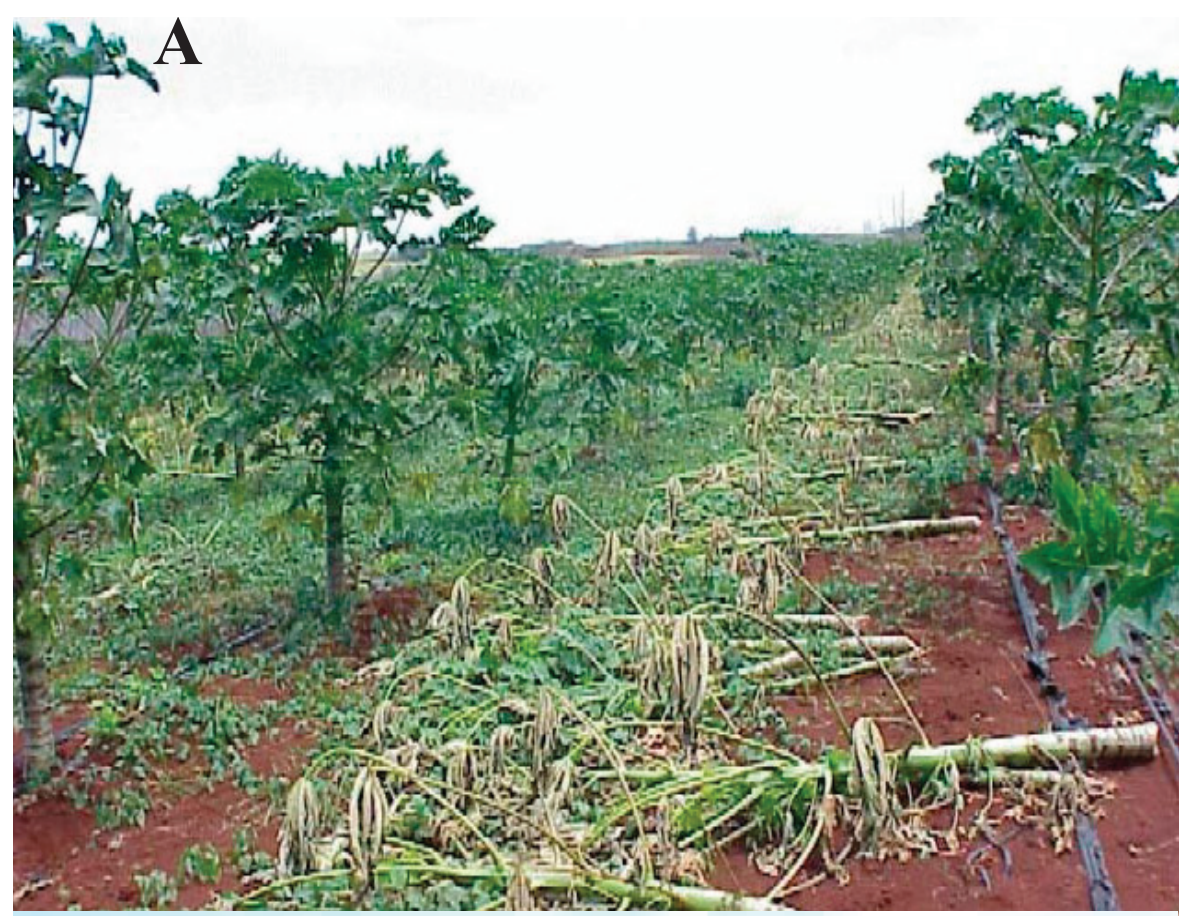

B

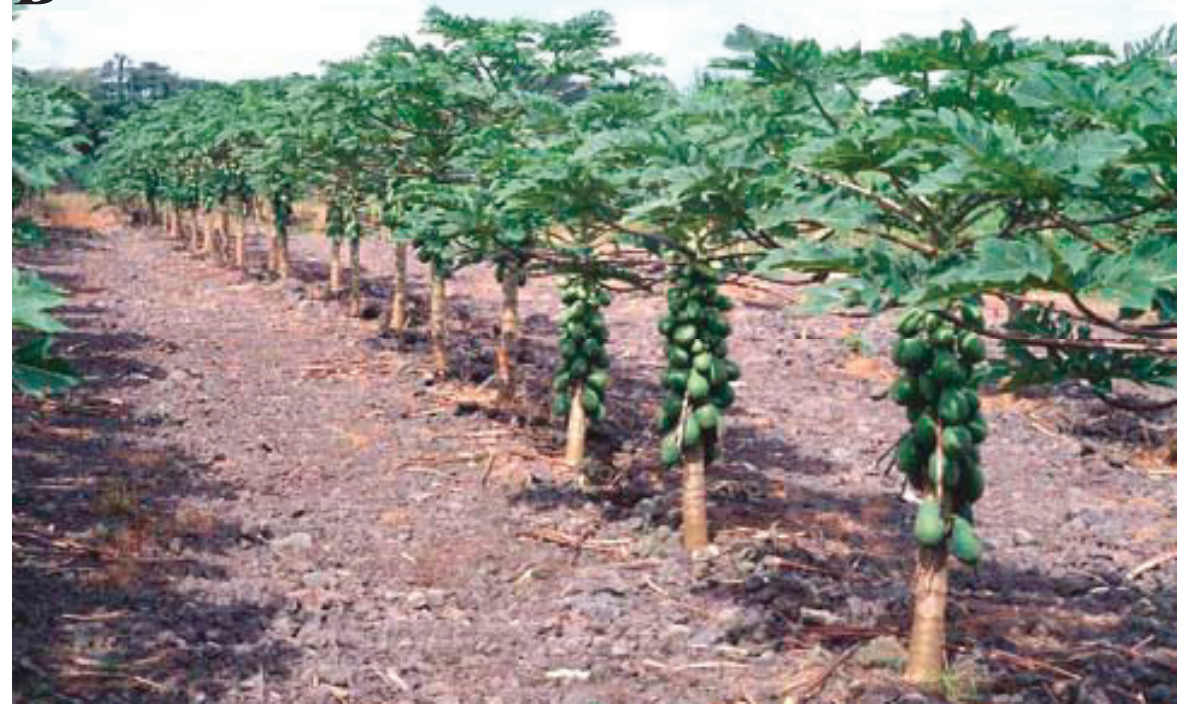

C

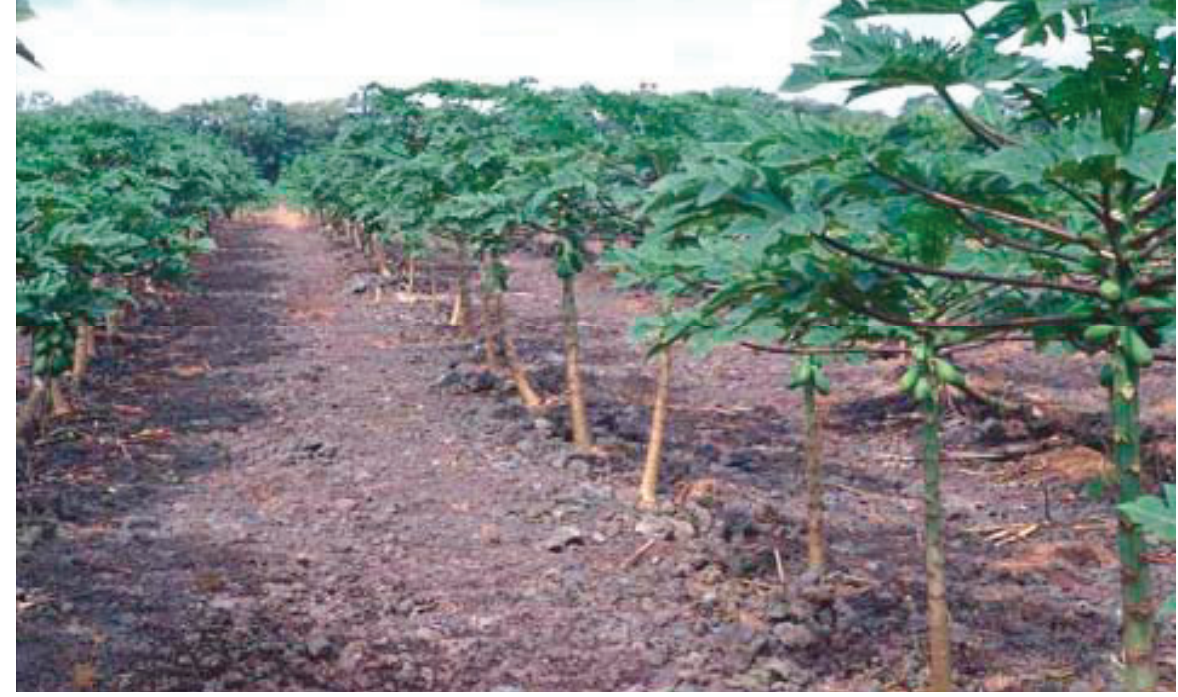

types was significantly higher than the SD5s (Table 3). Nearly all of the plants were in bud by the fifth month. Height of the first bud differed between the treatments with the SD5s flowering highest at $89.9 \mathrm{~cm}$ (1 plant) in the third month after transplant followed by SD1, $\mathrm{MP}_{\mathrm{l}}, \mathrm{MP}_{\mathrm{sm}}$, and CT plants (Table 4). By the fifth month, the SD5s were still significantly the highest bearing followed by SD1, MP, and $\mathrm{MP}_{\mathrm{sm}}$ plants which were all significantly higher bearing than CTs $(53.9 \mathrm{~cm})$. The fruit height remained the same for the next 2 months of measurement. Bud height averages varied from month to month as increasing numbers of trees developed buds and, occasionally, the earliest buds abscised. In the fifth month after transplanting, nearly all of the plants had formed buds so that bud height data for months 4 to 7 were nearly identical.

The percentage of trees with harvest height exceeding $183 \mathrm{~cm}$ (harvesting devices required) differed among the plant types (Table 4). At 18 months after transplanting, about one-third (33.8\%) of all SD5 trees had to be harvested with poles, a significantly higher percentage compared to $\mathrm{CT}(0 \%), \mathrm{MP}_{\mathrm{lg}}(1.3 \%)$ and $\mathrm{MP}_{\mathrm{sm}}(7.5 \%)$ plants. Harvesting poles were required for $15.6 \%$ of the SD1 plants, not significantly different from SD5 nor the clonally propagated plants.

Helemano height and diameter measurements were taken four times in the growth cycle (Table 5). Despite the small number of data points, significant differences were observed between the taller SD5 and clonally propagated plants in each sampling. There were no differences in diameter in the third to sixth months but micropropagated plants were thicker in the seventh month.

Bud heights 3 months after transplanting in Helemano were higher for SD5 plants (55.7\% budded) than for MPs (45\% budded) and CTs (35\% budded), but the data were not significantly different (Table 6). CTs continued to have a significantly lower percentage of trees with buds in the fourth month of growth. At 7 months of growth, all plants had formed flower buds, and SD5s were significantly higher bearing than MPs and CTs that were equal in bud height. Later in the growth cycle, more SD5 plants required harvesting devices compared to the clonally propagated plants (Table 7). An average of $91 \%$ of the SD5 exceeded 183 $\mathrm{cm}$ compared to $44 \%$ of the MPs and $32 \%$ of the CTs.

Plant types in Mokuleia differed significantly $(P<0.05)$ in height and but not diameter in the first month of growth (Table 8), a reflection of initial planting size differences. SD5 plants were significantly taller than all other plant types for the duration of the experiment. SD1 plants were taller than clonally propagated plants in the first 10 months of growth except for the third month when there was no differ-

Fig. 1. Contrasting methods for production of papaya. (A) Multiple-planted, thinned seedlings in a commercial field on Oahu. (B) Rooted cuttings and (C) multiple-planted, thinned seedlings 7 months after planting in lava in Keaau. The trees in $\mathbf{B}$ and C were transplanted at the same time. 
Table 2. Monthly growth of cloned or seedling papaya plants at the Keaau site.

\begin{tabular}{|c|c|c|c|c|c|c|c|c|c|}
\hline \multirow[b]{2}{*}{$\begin{array}{l}\text { Plant } \\
\text { type }^{z}\end{array}$} & \multicolumn{9}{|c|}{ Month (date) after transplanting cloned or seedling plants of papaya } \\
\hline & $\begin{array}{c}1 \\
\text { (May 1998) }\end{array}$ & $\begin{array}{c}2 \\
\text { (June 1998) }\end{array}$ & $\begin{array}{c}3 \\
\text { (July 1998) }\end{array}$ & $\begin{array}{c}4 \\
\text { (Aug. 1998) }\end{array}$ & $\begin{array}{c}5 \\
\text { Sept. 1998) }\end{array}$ & $\begin{array}{c}6 \\
\text { (Oct. 1998) }\end{array}$ & $\begin{array}{c}7 \\
\text { (Nov. 1998) }\end{array}$ & $\begin{array}{c}8 \\
\text { (Dec. 1998) }\end{array}$ & $\begin{array}{c}9 \\
\text { (Jan. 1999) }\end{array}$ \\
\hline \multicolumn{10}{|c|}{ Tree height $(\mathrm{cm})$} \\
\hline $\mathrm{CT}$ & $19.6 b^{y}$ & $40.6 \mathrm{~b}$ & $57.1 \mathrm{~b}$ & $80.2 \mathrm{~b}$ & $100.3 \mathrm{~b}$ & $116.7 \mathrm{a}$ & $133.3 \mathrm{a}$ & $136.7 \mathrm{~b}$ & $147.6 \mathrm{~b}$ \\
\hline $\mathrm{MP}_{\mathrm{lg}}$ & $30.4 \mathrm{a}$ & $53.4 \mathrm{a}$ & $73.2 \mathrm{a}$ & $96.6 \mathrm{ab}$ & $117.5 \mathrm{ab}$ & $133.5 \mathrm{a}$ & $149.2 \mathrm{a}$ & $158.0 \mathrm{ab}$ & $163.0 \mathrm{ab}$ \\
\hline $\mathrm{MP}_{\mathrm{sm}}^{\mathrm{lg}}$ & $19.3 \mathrm{~b}$ & $39.0 \mathrm{~b}$ & $61.0 \mathrm{ab}$ & $85.7 \mathrm{~b}$ & $111.5 \mathrm{ab}$ & $124.2 \mathrm{a}$ & $139.9 \mathrm{a}$ & $153.4 \mathrm{ab}$ & $155.2 \mathrm{ab}$ \\
\hline SD1 & $11.5 \mathrm{c}$ & $36.3 \mathrm{~b}$ & $58.9 \mathrm{ab}$ & $84.0 \mathrm{~b}$ & $108.1 \mathrm{ab}$ & $125.9 \mathrm{a}$ & $143.9 \mathrm{a}$ & $157.7 \mathrm{ab}$ & $160.3 \mathrm{ab}$ \\
\hline SD5 & $18.6 \mathrm{~b}$ & $42.4 \mathrm{~b}$ & $62.9 \mathrm{ab}$ & $105.7 \mathrm{a}$ & $129.5 \mathrm{a}$ & $143.1 \mathrm{a}$ & $160.6 \mathrm{a}$ & $173.0 \mathrm{a}$ & $180.0 \mathrm{a}$ \\
\hline \multicolumn{10}{|c|}{ Tree diameter $(\mathrm{cm})$} \\
\hline $\mathrm{CT}$ & $1.2 \mathrm{~b}$ & $2.5 \mathrm{~b}$ & $4.0 \mathrm{~b}$ & $5.7 \mathrm{ab}$ & $7.9 \mathrm{ab}$ & $8.2 \mathrm{a}$ & $10.0 \mathrm{ab}$ & $8.6 \mathrm{~b}$ & $9.5 \mathrm{a}$ \\
\hline $\mathrm{MP}_{\mathrm{lg}}$ & $1.5 \mathrm{a}$ & $3.2 \mathrm{a}$ & $4.8 \mathrm{a}$ & $6.6 \mathrm{a}$ & $9.0 \mathrm{a}$ & $9.3 \mathrm{a}$ & $11.2 \mathrm{~b}$ & $10.6 \mathrm{a}$ & $10.6 \mathrm{a}$ \\
\hline $\mathrm{MP}^{\mathrm{lg}}$ & $0.7 \mathrm{c}$ & $2.3 \mathrm{bc}$ & $3.7 \mathrm{bc}$ & $5.7 \mathrm{ab}$ & $8.0 \mathrm{ab}$ & $8.6 \mathrm{a}$ & $10.3 \mathrm{ab}$ & $10.1 \mathrm{ab}$ & $9.8 \mathrm{a}$ \\
\hline SD1 & $0.7 \mathrm{c}$ & $1.8 \mathrm{~cd}$ & $3.1 \mathrm{~cd}$ & $4.9 \mathrm{bc}$ & $7.0 \mathrm{~b}$ & $7.1 \mathrm{a}$ & $8.9 \mathrm{a}$ & $8.9 \mathrm{ab}$ & $9.1 \mathrm{a}$ \\
\hline SD5 & $0.6 \mathrm{c}$ & $1.6 \mathrm{~d}$ & $2.2 \mathrm{~d}$ & $3.7 \mathrm{c}$ & $7.0 \mathrm{~b}$ & $7.1 \mathrm{a}$ & $9.0 \mathrm{a}$ & $9.5 \mathrm{ab}$ & $10.0 \mathrm{a}$ \\
\hline
\end{tabular}

${ }^{{ }^{2} \mathrm{CT}}=$ cutting plants, $\mathrm{MP}_{\mathrm{lg}}=$ large micropropagated plants, $\mathrm{MP}_{\mathrm{sm}}=$ small micropropagated plants, $\mathrm{SD} 1=$ single hermaphrodite seedlings, SD5 = multiple-planted then thinned seedlings.

${ }^{\mathrm{y}}$ Mean values within a column followed by different letters indicate significant differences among treatments $(P<0.05)$ according to ANOVA (LSD).

Table 3. Percentage of cloned and seedling papaya plants in bud at Keaau.

\begin{tabular}{|c|c|c|c|c|c|}
\hline \multirow[b]{2}{*}{$\begin{array}{l}\text { Plant } \\
\text { type }\end{array}$} & \multicolumn{5}{|c|}{ Month (date) after transplanting cloned or seedling plants of papaya } \\
\hline & $\begin{array}{c}2 \\
\text { (June 1998) }\end{array}$ & $\begin{array}{c}3 \\
\text { (July 1998) }\end{array}$ & $\begin{array}{c}4 \\
\text { (Aug. 1998) }\end{array}$ & $\begin{array}{c}5 \\
\text { (Sept. 1998) }\end{array}$ & $\begin{array}{c}6 \\
\text { (Oct. 1998) }\end{array}$ \\
\hline$\overline{\mathrm{CT}}$ & 0 & $88.8 \mathrm{a}^{\mathrm{y}}$ & $98.8 \mathrm{a}$ & $100 \mathrm{a}$ & $100 \mathrm{a}$ \\
\hline $\mathrm{MP}_{\mathrm{lg}}$ & 0 & $92.5 \mathrm{a}$ & $100 \mathrm{a}$ & $100 \mathrm{a}$ & $100 \mathrm{a}$ \\
\hline $\mathrm{MP}_{\mathrm{sm}}^{\mathrm{lg}}$ & 0 & $54.3 \mathrm{~b}$ & $97.6 \mathrm{a}$ & $100 \mathrm{a}$ & $100 \mathrm{a}$ \\
\hline SD1 & 0 & $27.0 \mathrm{c}$ & $83.4 \mathrm{a}$ & $100 \mathrm{a}$ & $100 \mathrm{a}$ \\
\hline SD5 & 0 & $<1.0 \mathrm{~d}^{\mathrm{x}}$ & $60.2 \mathrm{~b}^{\mathrm{w}}$ & $95.0 \mathrm{a}^{\mathrm{w}}$ & $100 \mathrm{a}$ \\
\hline
\end{tabular}

${ }^{\mathrm{z}} \mathrm{CT}=$ cutting plants, $\mathrm{MP}_{\mathrm{lg}}=$ large micropropagated plants, $\mathrm{MP}_{\mathrm{sm}}=$ small micropropagated plants, $\mathrm{SD} 1=$ single hermaphrodite seedlings, SD5 = multiple-planted then thinned seedlings.

${ }^{\mathrm{y}}$ Mean values within a column followed by different letters indicate significant differences among treatments $(P<0.05)$ according to ANOVA (LSD).

${ }^{\mathrm{x}}$ One tree in four replication blocks

wData from females and hermaphrodites. Females were removed if sex expression could be determined.

ence. The diameter of all plant types did not differ in the growth cycle.

Buds were observed in the second month of growth in Mokuleia (Table 9), but the percentage of plants in bud was small, 3.6\% to $13.0 \%$, not significantly different between plant types. The percentage of plants in bud did not differ significantly over time. By the fourth month of growth, all plants had formed buds. Bud heights of CTs and MPs (Table 10) were significantly shorter than those of SDs for nearly the entire growth cycle until the first harvest 8 months after transplanting. The exceptions were in months 2 and 5 when bud height of the clonally propagated plants and the SD1 were not significantly different. Variations in monthly height data were a result of the changing number of mature plants and abscission of some early buds.

The first bud or fruit on SD5 plants was significantly higher compared to all other plant types from the third month of growth (Table 10). At the first harvest after 8 months of growth, fruit height of $7.5 \%$ of the SD5 trees exceeded $183 \mathrm{~cm}$, the maximum height for harvesting without additional devices like poles, ladders, scissorlifts, or forklifts. Ten months after transplanting, $>50 \%$ of the SD5 trees were harvested with ladders compared to $<2 \%$ of the other plant types. In the last data collection, 14 months after transplanting, the fruit of all plant types were harvested with ladders, but fruit height for SD5 plants was significantly higher than all other plants. Fruit height of MP plants was significantly lower than seedlings.

Large differences were observed in fruiting height of the plant types at the three test sites. At 18 months after transplanting, $>93 \%$ of all clonally propagated trees in Keaau and significantly fewer, $66 \%$, of the thinned seedlings were harvested without picking devices. In contrast, an average of $51 \%$ of thinned seedlings, but $<2 \%$ of all other plants in Mokuleia, required harvesting devices 10 months after planting. However, 4 months later, $>85 \%$ of all trees had to be harvested with ladders and there was no significant difference among the plant types.

\section{Discussion}

Trees grown from seed developed differently from the micropropagated or cuttingderived plants by being taller, bearing flowers and fruit higher on the stem, and flowering at an intermediate time. As in most species, this behavior can be explained by the known effect of the juvenility factor which persists longer in seedlings. These data however differ from those of Drew and Vogler (1993) who reported that clones micropropagated from juvenile tissue did not differ consistently from seedlings in height and node number of first flower and in growth parameters. These authors reported that only plants micropropagated from adult tissue had a reduced juvenile phase indicated by increased circumference, lower height of first flower, reduced time to harvest, and higher fruit numbers per measured stem. Different ecological conditions and different plant materials (dioecious lines in Australia) can possibly play a role in explaining the differences. The Mokuleia data support some of the Australian observations because, while $90 \%$ of the plants were micropropagated from juvenile tissue, they did not differ from single-planted seedlings in diameter, were shorter in height in only

Table 4. First bud or fruit height of cloned or seedling papaya plants at Keaau.

\begin{tabular}{|c|c|c|c|c|c|c|c|c|}
\hline \multirow[b]{2}{*}{$\begin{array}{l}\text { Plant } \\
\text { type }\end{array}$} & \multicolumn{7}{|c|}{ Month (date) after transplanting cloned or seedling papaya plants } & \multirow[b]{2}{*}{$\begin{array}{c}18 \\
\text { (Oct. 1999) }\end{array}$} \\
\hline & $\begin{array}{c}1 \\
\text { (May 1998) }\end{array}$ & $\begin{array}{c}2 \\
\text { (June 1998) }\end{array}$ & $\begin{array}{c}3 \\
\text { (July 1998) }\end{array}$ & $\begin{array}{c}4 \\
\text { (Aug. 1998) }\end{array}$ & $\begin{array}{c}5 \\
\text { Sept. 1998) }\end{array}$ & $\begin{array}{c}6 \\
\text { (Oct. 1998) }\end{array}$ & $\begin{array}{c}7 \\
\text { (Nov. 1998) }\end{array}$ & \\
\hline Bud or fruit height $(\mathrm{cm})$ & & & & & & & & $\begin{array}{c}\text { Trees with fruit } \\
\text { columns }>183 \mathrm{~cm}^{v}\end{array}$ \\
\hline $\mathrm{CT}$ & 0 & 0 & $49.4 \mathrm{~d}^{\mathrm{y}}$ & $54.0 \mathrm{c}$ & $53.9 \mathrm{~d}$ & $52.3 \mathrm{c}$ & $54.2 \mathrm{c}$ & $0 \mathrm{~b}$ \\
\hline $\mathrm{MP}_{\mathrm{lg}}$ & 0 & 0 & $66.9 \mathrm{bc}$ & $72.0 \mathrm{~b}$ & $70.9 \mathrm{bc}$ & $71.4 \mathrm{~b}$ & $69.8 \mathrm{~b}$ & $1.3 \mathrm{~b}$ \\
\hline $\mathrm{MP}_{\mathrm{sm}}^{\mathrm{Ig}}$ & 0 & 0 & $59.6 \mathrm{c}$ & $68.9 \mathrm{~b}$ & $66.7 \mathrm{c}$ & $67.4 \mathrm{~b}$ & $65.5 \mathrm{~b}$ & $7.5 \mathrm{~b}$ \\
\hline SD1 & 0 & 0 & $73.7 \mathrm{~b}$ & $76.4 \mathrm{~b}$ & $77.2 \mathrm{~b}$ & $75.8 \mathrm{~b}$ & $71.6 \mathrm{~b}$ & $15.6 \mathrm{ab}$ \\
\hline SD5 & 0 & 0 & $89.9 a^{x}$ & $106.3 \mathrm{a}$ & $103.8 \mathrm{a}$ & $106.8 \mathrm{a}$ & $104.1 \mathrm{a}$ & $33.8 \mathrm{a}$ \\
\hline
\end{tabular}

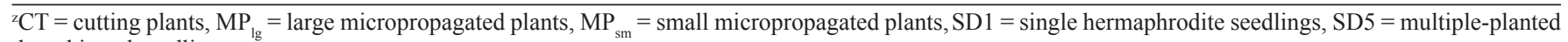
then thinned seedlings.

${ }^{y}$ Mean values within a column followed by different letters indicate significant differences among treatments $(P<0.05)$ according to ANOVA (LSD).

${ }^{\mathrm{x}}$ One tree in four replication blocks.

${ }^{\mathrm{v}}$ Column at the right $=$ percentage of trees requiring harvesting devices. 
Table 5. Monthly growth of cloned or seedling papaya plants at the Helemano site.

\begin{tabular}{lccccc}
\hline & \multicolumn{5}{c}{ Month (date) after transplanting cloned or seedling plants of papaya } \\
\cline { 2 - 6 } $\begin{array}{l}\text { Plant } \\
\text { type }\end{array}$ & $\begin{array}{c}2 \\
\text { (Dec. 1998) }\end{array}$ & $\begin{array}{c}3 \\
\text { (Jan. 1999) }\end{array}$ & $\begin{array}{c}4 \\
\text { (Feb. 1999) }\end{array}$ & $\begin{array}{c}6 \\
\text { (April 1999) }\end{array}$ & $\begin{array}{c}7 \\
\text { (May 1999) }\end{array}$ \\
\hline $\begin{array}{l}\text { Tree height (cm) } \\
\text { CT }\end{array}$ & ND $^{y}$ & $63.3 \mathrm{~b}^{\mathrm{x}}$ & $77.9 \mathrm{~b}$ & $128.3 \mathrm{~b}$ & $153.7 \mathrm{~b}$ \\
MP & ND & $66.3 \mathrm{~b}$ & $86.9 \mathrm{~b}$ & $130.4 \mathrm{~b}$ & $162.6 \mathrm{~b}$ \\
SD5 & ND & $88.6 \mathrm{a}$ & $112.9 \mathrm{a}$ & $172.9 \mathrm{a}$ & $205.1 \mathrm{a}$ \\
Tree diameter (cm) & & & & & \\
CT & ND & $4.7 \mathrm{a}$ & $5.5 \mathrm{a}$ & $10.3 \mathrm{a}$ & $12.1 \mathrm{~b}$ \\
MP & ND & $4.6 \mathrm{a}$ & $5.4 \mathrm{a}$ & $10.3 \mathrm{a}$ & $16.6 \mathrm{a}$ \\
SD5 & ND & $4.7 \mathrm{a}$ & $5.8 \mathrm{a}$ & $9.8 \mathrm{a}$ & $11.9 \mathrm{~b}$ \\
\hline
\end{tabular}

${ }^{{ }^{2} \mathrm{CT}}=$ cuttings, $\mathrm{MP}=$ micropropagated plants, $\mathrm{SD} 5=$ thinned seedlings.

${ }^{y} \mathrm{ND}=$ no data were collected.

${ }^{\mathrm{x}}$ Mean values within a column followed by different letters indicate significant differences among treatments $(P<0.05)$ according to ANOVA (LSD).

Table 6. Percentage of cloned or seedling papaya trees in bud at Helemano.

\begin{tabular}{lcccccc}
\hline & \multicolumn{5}{c}{ Month (date) after transplanting cloned or seedling papaya plants } \\
\cline { 2 - 7 } $\begin{array}{l}\text { Plant } \\
\text { type }\end{array}$ & $\begin{array}{c}1 \\
\text { (Nov. 1998) }\end{array}$ & $\begin{array}{c}2 \\
\text { (Dec. 1998) }\end{array}$ & $\begin{array}{c}\text { (Jan. 1999) } \\
\text { (Feb. 1999) }\end{array}$ & $\begin{array}{c}6 \\
\text { (April 1999) }\end{array}$ & $\begin{array}{c}7 \\
\text { (May 1999) }\end{array}$ \\
\hline CT & 0 & ND $^{\mathrm{y}}$ & $35.0 \mathrm{a}^{\mathrm{x}}$ & $76.7 \mathrm{~b}$ & $96.7 \mathrm{a}$ & $100 \mathrm{a}$ \\
MP & 0 & $\mathrm{ND}$ & $45.0 \mathrm{a}$ & $88.4 \mathrm{ab}$ & $98.3 \mathrm{a}$ & $100 \mathrm{a}$ \\
SD5 & 0 & ND & $55.7 \mathrm{a}^{\mathrm{w}}$ & $95.0 \mathrm{a}^{\mathrm{w}}$ & $100 \mathrm{a}$ & $100 \mathrm{a}$ \\
\hline
\end{tabular}

${ }^{2} \mathrm{CT}=$ cuttings, $\mathrm{MP}=$ micropropagated plants, $\mathrm{SD} 5=$ thinned seedlings.

${ }^{\mathrm{N} N D-n o}$ data were collected.

${ }^{\mathrm{x}}$ Mean values within a column followed by different letters indicate significant differences among treatments $(P<0.05)$ according to ANOVA (LSD).

"Females were removed after data were collected.

Table 7. First bud or fruit height of cloned or seedling papaya plants at Helemano.

\begin{tabular}{|c|c|c|c|c|c|c|c|}
\hline \multirow[b]{2}{*}{$\begin{array}{l}\text { Plant } \\
\text { type }\end{array}$} & \multicolumn{7}{|c|}{ Months and dates after transplanting cloned or seedling papaya plants } \\
\hline & $\begin{array}{c}1 \\
\text { (Nov. 1998) }\end{array}$ & $\begin{array}{c}2 \\
\text { (Dec. 1998) }\end{array}$ & $\begin{array}{c}3 \\
\text { (Jan. 1999) }\end{array}$ & $\begin{array}{c}4 \\
\text { (Feb. 1999) }\end{array}$ & $\begin{array}{c}6 \\
\text { (April 1999) }\end{array}$ & $\begin{array}{c}7 \\
\text { (May 1999) }\end{array}$ & $\begin{array}{c}14 \\
(\text { Dec. 1999) }\end{array}$ \\
\hline Bud or fruit height $(\mathrm{cm})$ & & & & & & & $\begin{array}{c}\text { Trees with fruit columns } \\
>183 \mathrm{~cm}(\%)^{\mathrm{y}}\end{array}$ \\
\hline $\mathrm{CT}$ & 0 & $\mathrm{ND}^{\mathrm{x}}$ & $66.2 \mathrm{a}^{\mathrm{w}}$ & $76.0 \mathrm{~b}$ & $80.9 \mathrm{~b}$ & $78.5 \mathrm{~b}$ & $31.7 \mathrm{~b}$ \\
\hline MP & 0 & ND & $70.2 \mathrm{a}$ & $71.3 \mathrm{~b}$ & $80.4 \mathrm{~b}$ & $78.1 \mathrm{~b}$ & $44.2 \mathrm{~b}$ \\
\hline SD5 & 0 & ND & $86.8 \mathrm{a}$ & $104.6 \mathrm{a}$ & $114.5 \mathrm{a}$ & $115.4 \mathrm{a}$ & $91.3 \mathrm{a}$ \\
\hline
\end{tabular}

${ }^{2} \mathrm{CT}=$ cuttings, ${ }^{\mathrm{y}} \mathrm{MP}=$ micropropagated plants, $\mathrm{SD} 5=$ thinned seedlings.

${ }^{y}$ Column at the right $=$ percentage of trees requiring harvesting devices.

${ }^{\mathrm{x}} \mathrm{ND}=$ no data were collected.

${ }^{\text {w}}$ Mean values within a column followed by different letters indicate significant differences among treatments $(P<0.05)$ according to ANOVA (LSD).

Table 8. Monthly growth of cloned or seedling papaya plants at the Mokuleia site.

\begin{tabular}{|c|c|c|c|c|c|c|c|c|c|c|c|c|c|c|}
\hline \multirow[b]{2}{*}{$\begin{array}{l}\text { Plant } \\
\text { type }^{z}\end{array}$} & \multicolumn{14}{|c|}{ Month (date) after transplanting cloned or seedling papaya plants } \\
\hline & $\begin{array}{c}1 \\
\text { (April } \\
1999 \text { ) }\end{array}$ & $\begin{array}{c}2 \\
\text { (May } \\
1999)\end{array}$ & $\begin{array}{c}3 \\
\text { (June } \\
1999)\end{array}$ & $\begin{array}{c}4 \\
\text { (July } \\
1999)\end{array}$ & $\begin{array}{c}5 \\
\text { (Aug. } \\
1999 \text { ) }\end{array}$ & $\begin{array}{c}6 \\
\text { (Sept. } \\
1999)\end{array}$ & $\begin{array}{c}7 \\
\text { (Oct. } \\
1999)\end{array}$ & $\begin{array}{c}8 \\
\text { (Nov. } \\
1999 \text { ) }\end{array}$ & $\begin{array}{c}9 \\
\text { (Dec. } \\
1999)\end{array}$ & $\begin{array}{c}10 \\
\text { (Jan. } \\
2000)\end{array}$ & $\begin{array}{c}11 \\
\text { (Feb. } \\
2000)\end{array}$ & $\begin{array}{c}12 \\
(\mathrm{March} \\
2000)\end{array}$ & $\begin{array}{c}13 \\
\text { (April } \\
2000)\end{array}$ & $\begin{array}{c}14 \\
\text { (May } \\
2000)\end{array}$ \\
\hline \multicolumn{15}{|c|}{ Height $(\mathrm{cm})$} \\
\hline $\mathrm{CT}$ & $27.9 \mathrm{c}^{\mathrm{y}}$ & $55.2 \mathrm{c}$ & $97.5 \mathrm{~b}$ & $126.5 \mathrm{c}$ & $167.7 \mathrm{c}$ & $195.1 \mathrm{bc}$ & $230.1 \mathrm{bc}$ & $265.6 \mathrm{c}$ & $275.8 \mathrm{bc}$ & $296.6 \mathrm{bc}$ & $308.5 \mathrm{~b}$ & $319.7 \mathrm{~b}$ & $340.6 \mathrm{~b}$ & $349.0 \mathrm{bc}$ \\
\hline MP & $33.2 \mathrm{c}$ & $57.1 \mathrm{bc}$ & $94.7 \mathrm{~b}$ & $121.7 \mathrm{c}$ & $162.8 \mathrm{c}$ & $187.7 \mathrm{c}$ & $222.6 \mathrm{c}$ & $251.1 \mathrm{c}$ & $269.5 \mathrm{c}$ & $287.2 \mathrm{c}$ & $301.1 \mathrm{~b}$ & $313.1 \mathrm{~b}$ & $330.2 \mathrm{~b}$ & $333.6 \mathrm{c}$ \\
\hline SD1 & $39.7 \mathrm{~b}$ & $63.7 \mathrm{~b}$ & $104.6 \mathrm{~b}$ & $143.3 \mathrm{~b}$ & $187.9 \mathrm{~b}$ & $210.6 \mathrm{~b}$ & 246.8 b & $287.3 \mathrm{~b}$ & $293.8 \mathrm{~b}$ & $312.4 \mathrm{~b}$ & $325.5 \mathrm{ab}$ & $327.3 \mathrm{~b}$ & $354.4 \mathrm{~b}$ & $360.1 \mathrm{~b}$ \\
\hline SD5 & $46.6 \mathrm{a}$ & $80.6 \mathrm{a}$ & $147.4 \mathrm{a}$ & $180.4 \mathrm{a}$ & $222.1 \mathrm{a}$ & $247.6 \mathrm{a}$ & $286.6 \mathrm{a}$ & $316.4 \mathrm{a}$ & $319.5 \mathrm{a}$ & $356.8 \mathrm{a}$ & $355.5 \mathrm{a}$ & $371.7 \mathrm{a}$ & $398.1 \mathrm{a}$ & $406.6 \mathrm{a}$ \\
\hline \multicolumn{15}{|c|}{ Diameter $(\mathrm{cm})$} \\
\hline $\mathrm{CT}$ & $1.4 \mathrm{a}$ & $3.6 \mathrm{a}$ & $7.1 \mathrm{a}$ & $10.3 \mathrm{a}$ & $14.5 \mathrm{a}$ & $17.7 \mathrm{a}$ & $18.3 \mathrm{a}$ & $20.2 \mathrm{a}$ & $20.3 \mathrm{a}$ & $20.6 \mathrm{a}$ & $20.6 \mathrm{a}$ & $21.0 \mathrm{a}$ & $20.9 \mathrm{ab}$ & $23.2 \mathrm{a}$ \\
\hline MP & $1.4 \mathrm{a}$ & $2.8 \mathrm{a}$ & $6.6 \mathrm{a}$ & $9.5 \mathrm{a}$ & $13.6 \mathrm{a}$ & $16.3 \mathrm{a}$ & $17.5 \mathrm{a}$ & $18.7 \mathrm{a}$ & $19.5 \mathrm{a}$ & $20.1 \mathrm{a}$ & $20.4 \mathrm{a}$ & $20.2 \mathrm{a}$ & $20.0 \mathrm{~b}$ & $20.2 \mathrm{a}$ \\
\hline SD1 & $1.5 \mathrm{a}$ & $3.6 \mathrm{a}$ & $6.7 \mathrm{a}$ & $10.4 \mathrm{a}$ & $14.6 \mathrm{a}$ & $17.5 \mathrm{a}$ & $18.4 \mathrm{a}$ & $20.1 \mathrm{a}$ & $20.4 \mathrm{a}$ & $20.6 \mathrm{a}$ & $21.0 \mathrm{a}$ & $21.0 \mathrm{a}$ & $20.8 \mathrm{ab}$ & $21.0 \mathrm{a}$ \\
\hline SD5 & $1.3 \mathrm{a}$ & $3.1 \mathrm{a}$ & $5.8 \mathrm{a}$ & $9.3 \mathrm{a}$ & $14.0 \mathrm{a}$ & $17.0 \mathrm{a}$ & $18.3 \mathrm{a}$ & $20.2 \mathrm{a}$ & $19.5 \mathrm{a}$ & $21.2 \mathrm{a}$ & $21.4 \mathrm{a}$ & $21.1 \mathrm{a}$ & $22.8 \mathrm{a}$ & $21.4 \mathrm{a}$ \\
\hline
\end{tabular}

${ }^{2} \mathrm{CT}=$ cuttings, $\mathrm{MP}=$ micropropagated plants, $\mathrm{SD} 1=$ single hermaphrodite seedlings, $\mathrm{SD} 5=$ thinned seedlings.

${ }^{y}$ Mean values within a column followed by different letters indicate significant differences among treatments $(P<0.05)$ according to ANOVA (LSD).

Table 9. Percentage of cloned or seedling papaya plants in bud at Mokuleia.

\begin{tabular}{lccc}
\hline & \multicolumn{3}{c}{ Months and dates after transplanting cloned or seedling papaya plants } \\
\cline { 2 - 4 } $\begin{array}{l}\text { Plant } \\
\text { type }^{z}\end{array}$ & $\begin{array}{c}2 \\
\text { (May 1999) }\end{array}$ & $\begin{array}{c}3 \\
\text { (June 1999) }\end{array}$ & $\begin{array}{c}\text { (April 1999) } \\
\text { CT }\end{array}$ \\
MP & $5.8 \mathrm{a}^{y}$ & $81.0 \mathrm{a}$ & $100 \mathrm{a}$ \\
SD1 & $5.0 \mathrm{a}$ & $78.9 \mathrm{a}$ & $100 \mathrm{a}$ \\
SD5 & $13.0 \mathrm{a}$ & $76.4 \mathrm{a}$ & $100 \mathrm{a}$ \\
\hline
\end{tabular}

${ }^{2} \mathrm{CT}=$ cuttings, ${ }^{\mathrm{y}} \mathrm{MP}=$ micropropagated plants, ${ }^{\mathrm{x}} \mathrm{SD} 1=$ single hermaphrodite seedlings, ${ }^{\mathrm{w}} \mathrm{SD} 5=$ thinned seedlings.

${ }^{y}$ Mean values within a column followed by different letters indicate significant differences among treatments $(P<0.05)$ according to ANOVA (LSD).

${ }^{x}$ Data for females and hermaphrodites. Females were removed if sex expression could be determined. 
Table 10. First bud or fruit height and percentage of cloned or seedling papaya plants requiring harvesting devices at Mokuleia.

\begin{tabular}{|c|c|c|c|c|c|c|c|c|c|c|c|c|c|}
\hline \multirow[b]{2}{*}{$\begin{array}{l}\text { Plant } \\
\text { type }\end{array}$} & \multicolumn{13}{|c|}{ Month (date) after transplanting cloned or seedling papaya plants ${ }^{2}$} \\
\hline & $\begin{array}{c}2 \\
\text { (May } \\
1999)\end{array}$ & $\begin{array}{c}3 \\
\text { (June } \\
1999)\end{array}$ & $\begin{array}{c}4 \\
\text { (July } \\
1999)\end{array}$ & $\begin{array}{c}5 \\
\text { (Aug. } \\
1999 \text { ) }\end{array}$ & $\begin{array}{c}6 \\
\text { (Sept. } \\
1999)\end{array}$ & $\begin{array}{c}7 \\
\text { (Oct. } \\
1999)\end{array}$ & $\begin{array}{c}8 \\
\text { (Nov. } \\
1999)\end{array}$ & $\begin{array}{c}9 \\
\text { (Dec. } \\
1999)\end{array}$ & $\begin{array}{c}10 \\
\text { (Jan. } \\
2000)\end{array}$ & $\begin{array}{c}11 \\
\text { (Feb. } \\
2000)\end{array}$ & $\begin{array}{c}12 \\
\text { (March } \\
2000)\end{array}$ & $\begin{array}{c}13 \\
\text { (April } \\
2000)\end{array}$ & $\begin{array}{c}14 \\
\text { (May } \\
2000)\end{array}$ \\
\hline \multicolumn{14}{|c|}{ Bud or fruit height $(\mathrm{cm})$} \\
\hline $\mathrm{CT}$ & $49.1 \mathrm{~b}^{\mathrm{x}}$ & $77.7 \mathrm{c}$ & $81.0 \mathrm{c}$ & $86.2 \mathrm{~b}$ & $81.1 \mathrm{c}$ & $79.8 \mathrm{c}$ & $83.7 \mathrm{c}$ & $94.4 \mathrm{c}$ & $130.2 \mathrm{~b}$ & $147.3 \mathrm{~b}$ & $166.8 \mathrm{~b}$ & $202.1 \mathrm{bc}$ & $214.1 \mathrm{bc}$ \\
\hline MP & $60.5 \mathrm{ab}$ & $80.2 \mathrm{c}$ & $83.8 \mathrm{c}$ & $85.2 \mathrm{~b}$ & $86.4 \mathrm{c}$ & $85.5 \mathrm{c}$ & $84.2 \mathrm{c}$ & $93.5 \mathrm{c}$ & $143.0 \mathrm{~b}$ & $144.5 \mathrm{~b}$ & $164.7 \mathrm{~b}$ & $194.7 \mathrm{c}$ & $207.9 \mathrm{c}$ \\
\hline SD1 & $72.0 \mathrm{a}$ & $88.1 \mathrm{~b}$ & $97.3 \mathrm{~b}$ & $94.3 \mathrm{~b}$ & $95.1 \mathrm{~b}$ & $93.7 \mathrm{~b}$ & $97.4 \mathrm{~b}$ & $102.4 \mathrm{~b}$ & $140.7 \mathrm{~b}$ & $155.6 \mathrm{~b}$ & $175.9 \mathrm{~b}$ & $212.6 \mathrm{~b}$ & $230.4 \mathrm{~b}$ \\
\hline SD5 & $79.1 \mathrm{a}$ & $128.5 \mathrm{a}$ & $137.0 \mathrm{a}$ & $137.1 \mathrm{a}$ & $135.0 \mathrm{a}$ & $135.9 \mathrm{a}$ & $133.1 \mathrm{a}$ & $142.9 \mathrm{a}$ & $181.2 \mathrm{a}$ & $181.4 \mathrm{a}$ & $214.6 \mathrm{a}$ & $250.2 \mathrm{a}$ & $268.2 \mathrm{a}$ \\
\hline \multicolumn{14}{|c|}{ Ttrees bearing fruit higher than $183 \mathrm{~cm}(\%)$} \\
\hline CT & & & & & & & $0 \mathrm{~b}$ & $0 \mathrm{~b}$ & $0 \mathrm{~b}$ & $8.0 \mathrm{~b}$ & $21.2 \mathrm{c}$ & $77.5 \mathrm{ab}$ & $88.8 \mathrm{a}$ \\
\hline MP & & & & & & & $0 \mathrm{~b}$ & $0 \mathrm{~b}$ & $0 \mathrm{~b}$ & $8.5 \mathrm{~b}$ & $28.6 \mathrm{bc}$ & $68.5 \mathrm{c}$ & $85.6 \mathrm{a}$ \\
\hline SD1 & & & & & & & $0 \mathrm{~b}$ & $0 \mathrm{~b}$ & $1.0 \mathrm{~b}$ & $6.5 \mathrm{~b}$ & $47.4 \mathrm{~b}$ & $86.2 \mathrm{ab}$ & $90.8 \mathrm{a}$ \\
\hline SD5 & & & & & & & $7.5 \mathrm{a}$ & $4.2 \mathrm{a}$ & $50.9 \mathrm{a}$ & $57.4 \mathrm{a}$ & $83.8 \mathrm{a}$ & $93.1 \mathrm{a}$ & $96.0 \mathrm{a}$ \\
\hline
\end{tabular}

${ }^{2}$ Monthly measurements up to the eighth month for height of first fruit; thereafter the data represent fruiting height.

${ }^{\mathrm{y}} \mathrm{CT}=$ cuttings, $\mathrm{MP}=$ micropropagated plants, $\mathrm{SD} 1=$ single hermaphrodite seedlings, $\mathrm{SD} 5=$ thinned seedlings.

${ }^{x}$ Mean values within a column followed by different letters indicate significant differences among treatments $(P<0.05)$ according to ANOVA (LSD).

5 of the 14 months of growth and had lower bud or fruit height in only the earliest months of growth (6 of the 14 months). Mokuleia had high levels of solar irradiation coupled with the highest average daily temperatures. Juvenility was pronounced in the first 3 months of growth in Keaau micropropagated plants all of which were derived from seedling tissues. Both large and small micropropagated plants were significantly shorter than single seedlings in the first month of growth and the percentage of micropropagated trees in bud was significantly higher than single seedlings when buds were first observed 3 months after transplant.

Before beginning this project, there was some concern that micropropagated plants might not develop a sufficiently sturdy root system since they would not have tap roots, or that the trees might senesce earlier, or the micropropagated plants might not be as productive as seedlings. None of these problems were observed and our results corroborate those of earlier studies by Allan (1964, 1993), Chan and Teo (2002), Drew (1988), and Drew and Vogler (1993) that showed earlier and lower flowering and fruiting of clonally propagated papayas compared to thinned seedlings. Allan in South Africa and Drew in Australia studied dioecious papayas that are generally grown in temperate regions where cooler winters result in serious fruit losses as a result of carpellody and male sterility. In those more temperate zone systems, maximum production is obtained by surrounding female trees with pollen bearing male trees. Our micropropagated plants fruited at 54 to $84 \mathrm{~cm}$, comparable to micropropagated hermaphrodite Hawaiian type papayas in Malaysia at $80 \pm 8 \mathrm{~cm}$ (Chan and Teo, 2002), which was higher than with the dioecious Australian trees at 30 to $40 \mathrm{~cm}$ (Drew, 1988). Thinned seedlings in Hawaii fruited at 104 to $137 \mathrm{~cm}$ vs. $105 \pm 38 \mathrm{~cm}$ for similar genotypes in Malaysia and 150 to $200 \mathrm{~cm}$ for dioecious genotypes in Australia. Australian papayas showed the greatest differences in fruiting height between micropropagated plants and thinned seedlings. Neither they nor we observed significant differences in tree diameter.

Zhou and coworkers (2000) studied the physiological effects of source (photosynthetic leaf, assimilate) on sink (fruit or fruit set) in papaya and reported that if the size of assimilate capacity were larger than the sink demand, then new flowers and fruit would continue to be set. While node number counts predict the transition time from juvenile to adult papaya for any given cultivar (Nakasone and Storey, 1955), those data may be another manifestation of the source or sink concept in flower bud initiation. Apparently the clonally propagated plants in Keaau had avoided juvenility to form flowers earlier than both single-planted and thinned seedlings. More rapid growth in Mokuleia and Helemano, most likely as a result of higher temperature, solar radiation, and fertility, may have minimized the juvenile period in seedlings since they flowered at about the same time and rate as the clonally propagated plants. While there was no apparent advantage to eliminate crowding on seedlings in terms of the timing and percentage of all plants to form flower buds, flowering height was highest in thinned seedlings at all three locations. Thus, while clonally propagated plants flowered earlier than seedlings in Keaau, the major effect of clonally propagated plants at all three locations was the lower flowering height. The shorter clonally propagated trees being easier to harvest for a few months in the cropping cycle, help to reduce harvest costs and consequently benefits growers.

Variation in plant phenotype, a problem associated with in vitro propagation, was not observed in this study that included $350 \mathrm{mi}$ cropropagated trees, $>80 \%$ of which originated from nine in vitro-germinated seedlings. Drew and Vogler (1993) described four dwarf offtype plants ( $<1 \%$ of population) that originated from a single bud explant. Since the Australian off-types were traced to a single bud from the selected mature tree, we believe that the variation originated from the tree rather than from tissue culture manipulations. In our experience with hybrid papaya trees, we observed at least five seedlings among several thousand that had thicker than normal leaves, petioles and stems, larger than normal flowers and leaf scars, and were nearly sterile. We believed they were tetraploids but did not check ploidy. At least two of the sterile trees developed fertile, normal-looking lateral branches that we rooted as cuttings and that produced normal-looking fruit in highly productive fruit columns.

The major bottlenecks to clonal propagation are 1) high cost of production as a result of low survival rates of plants grown as rooted cuttings or micropropagated plants and 2) timed output of propagules to enable farmers to plant when fields are prepared. In reference to the first bottleneck, our experience in scaling up production showed that problems with contamination prevented high throughput (Fitch et al., 2003a, 2003b). Therefore, we have revised protocols in which losses as a result of contamination are minimized, for example, decreasing or removing sugar from some of the growth media and incorporating bacteriocides in the media. To address the second bottleneck we note that plants can be maintained for a few months in the greenhouse or nursery the same as seedlings.

The vegetative cutting technology initiated from lateral branches is limited by the number of branches that can be harvested from selected trees. While this method may be adequate for the small numbers of plants required for the backyard gardener or small grower, micropropagation has the greater potential for providing enough plants for the 1500 ha under cultivation in Hawaii.

\section{Literature Cited}

Allan, P.1964. Papaws grown from cuttings. Farm. S. Afr. 39:35-40.

Allan, P. 1993. Propagation of 'Honey Gold' papayas by cuttings. Acta Hort. 370:99-102.

Chan, L.K. and C.K.H. Teo. 2002. Micropropagation of 'Eksotika', a Malaysian papaya cultivar and the field performance of the tissue culture derived clones. Acta Hort. 575:99-105.

de Fossard, R.A., A. Myint, and E.C.M. Lee.1974. A broad spectrum tissue culture experiment with tobacco (Nicotiana tabacum L.) pith callus tissue. Physiol. Plant. 31:125-130.

Dellaporta, S.L., J. Wood, and J.B.Hicks.1983. A plant DNA minipreparation: Version II. Plant Mol. Biol. Rpt. 5:387-405.

Deputy, J.C., R. Ming, M.M.M. Fitch, R. Manshardt, and J.I. Stiles. 2002. Molecular markers for sex determination in papaya (Carica papaya L.) Theor. Appl. Genet.106:107-111.

Drew, R.A. 1988. Rapid clonal propagation of papaya in vitro from mature field-grown trees. HortScience 23:609-611.

Drew, R.A., J.A. Macomb, and J.A. Considine. 1993. Rhizogenesis and root growth of Carica papaya $\mathrm{L}$. in vitro in relation to auxin sensitive phases and use of riboflavin. Plant Cell Tiss. Org. Cult. 33:1-7.

Drew, R.A. and J.N. Vogler. 1993. Field evaluation of tissue-cultured papaw clones in Queensland. Austr. J. Expt. Agr. 33:475-479.

Fitch, M.M.M., R.M. Manshardt, D. Gonsalves, J.L. Slightom, and J.C. Sanford. 1992. Virus resistant papaya plants derived from tissues bombarded 
with the coat protein gene of papaya ringspot virus. Bio/Technology 10:1466-1472.

Fitch, M., T. Leong, N. Saito, G. Yamamoto, A. Dela Cruz,A. Yeh, S. White, S. Maeda, S. Ferreira, and P. Moore. 2003a. Control of bacterial contamination in large scale papaya micropropagation. In Vitro Cell Dev. Biol. 39:19-A (abstr.).

Fitch, M., T. Leong, N. Saito, G. Yamamoto, A. Dela Cruz, A. Yeh, S. White, S. Maeda, S. Ferreira, and P. Moore. 2003b. Photoautotrophic rooting and growth of papayas in vitro, p. 131. Annu. Meeting Amer. Soc. Plant Biol. Suppl.

Hofmeyr, J.D.J. 1938. Genetical studies of Carica papaya L. S. Afr. J. Sci. 35:300-304.

How, K. 1978. Solar radiation in Hawaii 1932-1975, report R57. Div. Water Land Dev., Dept. Land Natural Resour., State of Hawaii, Honolulu.

Litz, R.E. and R.A. Conover. 1977. Tissue culture propagation of papaya. Proc. Fla. State Hort. Soc. 90:245-246.

Murashige, T. and F. Skoog. 1962.Arevised medium for rapid growth and bioassays with tobacco tissue cultures. Physiol. Plant. 15:473-497.

Nakasone, H.Y. and W.B. Storey. 1955. Studies on the inheritance of fruiting height of Carica papaya $\mathrm{L}$. Proc. Amer. Soc. Hort. Sci. 66:168-182.

Reuveni, O. and D.R. Shlesinger. 1990. Rapid vegetative propagation of papaya plants by cuttings. Acta Hort. 275:301-306.

Reuveni, O., D.R. Shlesinger, and U. Lavi. 1990. In vitro clonal propagation of dioecious Carica papaya. Plant Cell Tiss. Org. Cult. 20:41-46.

Saghai-Maroof, M.A., K.M. Soliman, R.A. Jorgensen, and R.W. Allard. 1984. Ribosomal DNA spacer-length polymorphisms in barley: Mendelian inheritance, chromosomal location, and population dynamics. Proc. Natl. Acad. Sci. USA 81:8014-8018.

Sondur, S., R.M. Manshardt, and J. Stiles. 1996. A genetic linkage map of papaya based on randomly amplified polymorphic DNA markers. Theor. Appl. Genet. 93:547-553.

Statistix 7 for Windows. 2000. Analytical software. Support@statistix.com.

Storey, W.B. 1938. Segregations of sex types in Solo papaya and their application to the selection of seed. Proc. Amer. Soc. Hort. Sci. 35:83-85.

Storey, W.B. 1939. Papaya. Hawaii Agr. Expt. Sta.
Rpt. 1938:11-12.

Storey, W.B. 1941. The botany and sex relations of the papaya. Hawaii Agr. Expt. Sta. Bull. 87:5-22.

Storey, W.B. 1953. Genetics of papaya. J. Hered. 44:70-78.

U.S. Department of Agriculture Soil Conservation Service. 1972. Soil survey of the islands of Kauai, Oahu, Maui, Molokai, and Lanai, State of Hawaii.

U.S. Department of Agriculture Soil Conservation Service. 1973. Soil survey of the island of Hawaii, State of Hawaii.

U.S. Geologic Survey. 1996. Geologic map of Hawaii Island. Edward W. Wolfe and Jean Morris, sheet 2.

Yu, T.-A., S.-D. Yeh, Y.-H. Cheng, and J.-S. Yang. 2000. Efficient rooting for establishment of papaya plantlets by micropropagation. Plant Cell Tiss. Org. Cult. 61:29-35.

Zhou, L., D.A.Christopher, and R.E. Paull. 2000 Defoliation and fruit removal effects on papaya fruit production, sugar accumulation, and sucrose metabolism. J. Amer. Soc. Hort. Sci. 125:644-652. 